\title{
Greenhouse gas and ammonia emissions from soil: The effect of organic matter and fertilisation method
}

\author{
Leonardo Verdi, ${ }_{1}^{1}$ Marco Mancini, ${ }^{1}$ Mirjana Ljubojevic, ${ }^{2}$ Simone Orlandini, ${ }^{1}$ \\ Anna Dalla Marta ${ }^{1}$
}

\author{
${ }^{1}$ Department of Agrifood Production and Environmental Sciences, University of Florence, Italy; \\ ${ }^{2}$ Department for Fruit Growing, Viticulture, Horticulture and Landscape Architecture, Faculty of \\ Agriculture, Novi Sad, Serbia
}

\begin{abstract}
Greenhouse gas (GHGs) emissions into the atmosphere derived from the use of fertilisers is a serious issue for the sustainability of agricultural systems, also considering that the growing global demand for food requires an increasingly productive agriculture. Emissions dynamics are very variable and are determined by many factors and their reciprocal interactions. Among driving factors, soil type (mineral, organic and microbiological composition), fertilisation method, climate, and the cropping system. In the present experiment, the combined effect of soil organic matter (SOM) and fertilisation method on the emissions of GHGs and
\end{abstract}

Correspondence: Leonardo Verdi, Department of Agrifood Production and Environmental Sciences (DISPAA), University of Florence, Piazzale delle Cascine 18, 50144 Firenze, Italy.

Tel.: +39.055.275.5741.

E-mail: leonardo.verdi@unifi.it

Key words: Agriculture; carbon; nitrogen; compost; digestate; static chamber.

Acknowledgements: the author thank Department of Agrifood Production and Environmental Sciences (DISPAA) of University of Florence for the financial support; the Department for Fruit Growing, Viticulture, Horticulture and Landscape Architecture, Faculty of Agriculture of Novi Sad for technical support on the production of this manuscript. Moreover, the authors thank Azienda Agricola Marchese De' Frescobaldi, Fattoria di Corte and Alia Servizi Ambientali Spa for kindly providing digestate and compost; and Roberto Vivoli from DISPAA for his assistance in the field. This article is supported by the H2020-TWINN-2015 SERBIA FOR EXCELL project. This project has received founding from the European Union's Horizon 2020 research and innovation program under grant agreement No. 691998.

Received for publication: 9 October 2017.

Revision received: 17 January 2018.

Accepted for publication: 22 January 2018.

CCopyright L. Verdi et al., 2018

Licensee PAGEPress, Italy

Italian Journal of Agronomy 2018; 13:1124

doi:10.4081/ija.2018.1124

This article is distributed under the terms of the Creative Commons Attribution Noncommercial License (by-nc 4.0) which permits any noncommercial use, distribution, and reproduction in any medium, provided the original author(s) and source are credited. ammonia $\left(\mathrm{NH}_{3}\right)$ was investigated. Liquid fraction of digestate from pig slurries, compost from organic fraction of municipal solid wastes, and urea were applied on bare soil with two levels of organic matter (OM1: 1.3\% and OM2: 4.3\%). Emissions were directly monitored by a static chamber system and a portable gas analyser. Results show that soil organic matter as well as the composition of the fertilisers affect greenhouse gasses emissions. Emissions of methane $\left(\mathrm{CH}_{4}\right)$ produced by digestate and compost during experimental period were higher in correspondence of lower organic matter content $\left(0.58-0.49 \mathrm{~kg} \mathrm{CH}_{4} \mathrm{C} /\right.$ ha/day and 0.37-0.32 $\mathrm{kg} \mathrm{CH}_{4} \mathrm{C} / \mathrm{ha} /$ day for digestate and compost respectively), contrary to what was observed for urea. For all fertilisers, carbon dioxide $\left(\mathrm{CO}_{2}\right)$ and nitrous oxide $\left(\mathrm{N}_{2} \mathrm{O}\right)$ emissions were higher in correspondence of higher organic matter level. In particular, $\mathrm{CO}_{2}$ emissions were $11.05 \%, 67.48 \%$ and $82.84 \%$ higher in OM2 than OM1 for digestate, urea and compost respectively. Likewise, $\mathrm{N}_{2} \mathrm{O}$ emissions were $87.45 \%, 68.97 \%$ and $92.11 \%$ higher in $\mathrm{OM} 2$ than OM1 for digestate, urea and compost respectively. The obtained results show that the content of organic matter in soils plays a key role on the emissions of GHGs, generally enhancing the levels of gas emissions.

\section{Introduction}

Several strategies were developed and proposed in the last decades to reduce the environmental impacts from agriculture. In particular, fertilisation is one of the most studied practices due to its detrimental effects on the environment, such as groundwater pollution, eutrophication and greenhouse gasses (GHGs) emissions. An alternative to chemical fertilisers is the use of recycled organic waste materials, as slurries and manure, characterised by low environmental impact and satisfactory crop yields (Alburquerque et al., 2012; Walsh et al., 2012).

In addition to slurry, organic wastes from household and food processing industries are increasingly used as fertilisers in agricultural systems (Alluvione et al., 2010). Of increasing relevance in this context is the combined anaerobic fermentation of organic wastes with slurry in biogas (Wulf et al., 2002) and compost plants. On the other hand, the inputs of organic matter (OM) into the soil play a key role in the productivity of arable land by providing nutrients, through decomposition, and by maintaining soil fertility through OM turnover (Palm et al., 2001). Researchers (Miller and Wali, 1995) have increasingly emphasised the benefits of a balanced fertilisation, by using organic amendment (e.g., crop residues, manure, compost) for enhancing or maintaining soil OM level in soils. However, the efficient and appropriate use of organic fertilisers coming from organic wastes requires more in-depth 
knowledge both in terms of quality and fertiliser value (Rowell et al., 2001) aiming to support crop production and protect the environment while saving the soil resource (Mamo et al., 1999). Moreover, a deep knowledge is also required for managing organic fertilisers.

Digestate management plays an important role on the real GHGs impact reduction. Due to its composition, rich in easily available nitrogen $(\mathrm{N})$ for plants and organic carbon (C) (Alburquerque et al., 2012), digestate can increase emissions of ammonia $\left(\mathrm{NH}_{3}\right)$ and $\mathrm{GHG}$ such as carbon dioxide $\left(\mathrm{CO}_{2}\right)$, methane $\left(\mathrm{CH}_{4}\right)$, nitrous oxide $\left(\mathrm{N}_{2} \mathrm{O}\right)$. An excessive application of digestate to agricultural soil without taking into account strategy to minimise losses through emissions can represent a point of weakness of the system. Within this context, the definition of appropriate management techniques represents one of the best opportunities for GHGs mitigation (Pezzolla et al., 2012).

Bouwman et al. (2010) suggested that the recycling of $\mathrm{N}$ in animal manure, human excreta and compost to reduce inorganic fertiliser decreased $\mathrm{N}_{2} \mathrm{O}$ emissions from agricultural ecosystems. In a Spanish typic xerofluent with a sandy loam texture, LopezFernandez et al. (2007) demonstrated that organic fertilisers reduced $\mathrm{N}_{2} \mathrm{O}$ emissions by $74 \%$ (compost) to $27 \%$ (pig slurry) in comparison with urea. This reduction was due to the consumption of $\mathrm{N}_{2} \mathrm{O}$ by denitrifying bacteria during the irrigation period, which was driven by the addition of labile organic C (Vallejo et al., 2006). In contrast, Hayakawa et al. (2009) observed that adding poultry manure and especially pelleted poultry manure to an andisol increased $\mathrm{N}_{2} \mathrm{O}$ emissions by approximately 2 and 7 times, respectively, but reduced NO emissions by $49 \%$ and $56 \%$, respectively, compared with inorganic fertiliser. These inconsistent results and reports in the literature may reflect differences in manure composition, $\mathrm{C}: \mathrm{N}$ ratios, incorporation method and depth into the soil, and the effect of their interaction with soil properties, such as soil organic carbon (SOC) and texture, on $\mathrm{N}_{2} \mathrm{O}$ production under different environmental, soil moisture and temperature conditions (Huang et al., 2004; van Groenigen et al., 2004; Stehfest and Bouwman, 2006).

For a better understanding of the emission dynamics from agricultural lands, particular attention has to be addressed to the system in absence of crops, which of course affect $\mathrm{N}$ and $\mathrm{C}$ cycles through uptake and assimilation processes. As affirmed by several authors, nowadays available data are scarce and referred only to specific areas and crops (Le Mer and Roger, 2001; Oertel et al., 2016). Authors affirm there is an inadequate data availability in Mediterranean area, and bare soil in general, with a strong bias towards temperate climate regions. Le Mer and Roger (2001) observed that available data on $\mathrm{CH}_{4}$ emissions are mainly focused on wetlands that represent the main source of $\mathrm{CH}_{4}$ from soils. In this way, upland $\mathrm{CH}_{4}$ emission dynamics are less explored. Despite the fact that $\mathrm{N}_{2} \mathrm{O}$ emissions are widely explored, contradictory results are observed regarding the effect of soil organic matter on $\mathrm{N}_{2} \mathrm{O}$ emissions. Velthof et al. (2003) observed that an addiction of organic c on arable soils encourage $\mathrm{N}_{2} \mathrm{O}$ emissions through denitrification. However, authors recommend further investigation on the interaction between manure/fertiliser composition and soil characteristic and utilisation. Instead, Oertel et al. (2016) reported a different behavior and described how the addiction of OM into the arable soils decrease $\mathrm{N}_{2} \mathrm{O}$ emissions. Considering the often discordant results, but also the great variability of soil and fertiliser compositions, and the influence of local climate factors (temperature, rainfall, wind, etc.), GHGs emissions dynamics need more indepth specific investigations. Moreover, as affirmed by Minoli et al. (2015), also $\mathrm{NH}_{3}$ emission dynamics need a deep-in-knowledge assessment mainly due, especially for Italy, to inconsistencies in the measurement methods. The aim of this research is to study the emissions (GHGs and $\mathrm{NH}_{3}$ ) of liquid fraction of digestate and compost after incorporation into bare soil, and to investigate the effect of organic matter in emission dynamics.

\section{Materials and methods}

Experimental field was located at the ITAGR (Istituto Tecnico

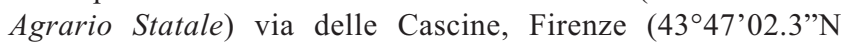
$\left.11^{\circ} 13^{\prime} 13.4^{\prime \prime} \mathrm{E}\right)$, Italy. The experiment was conducted on 24 pots (9.5 L volume) $24 \mathrm{~cm}$ high and diameter of $24 \mathrm{~cm}$, placed in the open field and exposed to the environmental conditions. Each pot was filled with $8 \mathrm{~kg}$ of a silty-clay soil (24\% clay, $31 \%$ silt and $45 \%$ sand) from experimental fields of Consiglio per la ricerca in agricoltura e l'analisi dell'economia agraria - Centro di ricerca per l'agrobiologia e la pedologia (CREA-ABP) located in

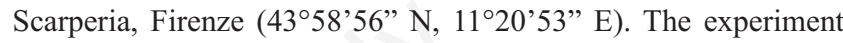
was set on bare soil in order to investigate the effect of the different fertilisers excluding any possible interference of the crop.

A layer of $30 \mathrm{~cm}$ of soil was taken from the experimental site including top and sub soil layer, and mixed before filling the pots in order to homogenise it. Soil sample was analysed in laboratory for elemental characterisation (Table 1). Experimental design consisted of two contrasting levels of soil organic matter - OM1 1.3\% (that was the original OM content in the soil) and OM2 4.3\% - with four treatments. Enrichment of OM into the soil was performed by adding $320 \mathrm{~g} \mathrm{pot}^{-1}$ of commercial manure, GoldenAgro Ecolife, (from poultry, piggery and horse manure) with $25 \%$ of organic $\mathrm{C}$ content and $2 \%$ of total $\mathrm{N}$, which did not significantly affected soil mineral composition.

Treatments included two types of organic fertilisers (liquid fraction of digestate from pig slurries and compost from organic fraction of municipal solid waste) as well as one organo-mineral fertiliser (urea), with the non-fertilised pots as control treatment. Replicates were carried out in a randomised block design. The digestate was produced by Fattoria di Corte Marchesi De' Frescobaldi farm (Florence, Italy, 4358'29” N, 11²3’21” E), while the compost derived from composting plant of Alia Servizi Ambientali Spa (Florence, Italy, 435' 580.95" N, 11²1'00.09' E). The amount of each fertiliser varied according to its $\mathrm{N}$ content (Table 2) and was calculated on the base of a pre-defined quantity of $150 \mathrm{~kg} \mathrm{~N} / \mathrm{ha}$. Fertilisers were incorporated into the soil by manually replacing injection, for digestate and mechanical harrowing incorporation for compost and urea. Immediately after fertilisation, the anchors were placed into the soil (10 cm depth) and the cham-

Table 1. Soil characterisation.

\begin{tabular}{lcc} 
& Unit & Soil \\
Texture & & \\
Silt & $\%$ & 31 \\
Clay & $\%$ & 24 \\
Sand & $\%$ & 45 \\
N total & $\%$ & 0.14 \\
\hline P total & $\%$ & 0.07 \\
K total & $\%$ & 0.23 \\
\hline pH & & 8.06 \\
\hline
\end{tabular}


bers were connected. Emission measurements were conducted three times in the first week after fertilisation ( $0 \mathrm{~h}, 48 \mathrm{~h}$ and $96 \mathrm{~h})$ and once a week in the following three weeks to investigate the emission trend (26 days of measuring period). In accordance to Parkin and Venterea (2010), measurements were performed in mid-morning - early evening (times more closely corresponding to the daily average temperatures) to account diurnal variability. Experimental pots remained opened between successive measurements to enable volatilisation, as these conditions would be the closest to the ones occurring naturally. $\mathrm{CO}_{2}, \mathrm{CH}_{4}, \mathrm{~N}_{2} \mathrm{O}$ and $\mathrm{NH}_{3}$ emission rates were measured by means of a static chambers system (Parkin and Ventera, 2010), equipped by two thermocouples per chamber, and a portable gas analyser XCGM 400 (Madur) that use nondispersive infrared sensors (NDIR) technology for $\mathrm{CO}_{2}$, $\mathrm{CH}_{4}$ and $\mathrm{N}_{2} \mathrm{O}$ analysis and electrochemical technology for $\mathrm{NH}_{3}$. Chambers are composed of two parts: the lid of the chamber (cylinder of $20 \mathrm{~cm}$ of diameter and $25 \mathrm{~cm}$ high) and the anchor system (cylinder of $20 \mathrm{~cm}$ diameter and $15 \mathrm{~cm}$ high). Samplings were performed by holding a needle, connected to XCGM 400, inside the chamber for 1-min recording gas accumulation at time 0 (immediately after chamber closing) and at time 1 (after $1 \mathrm{~h}$ ).

Gas fluxes were calculated starting from the gas concentration into the chamber, chamber dimensions (area and volume), closing time and molecular weight of each gas. As temperature had a similar trend inside each chamber (data not shown), the whole experiment was assumed to be at standard temperature and pressure (STP) conditions and the molar volume of the air is assumed as $22.4 \mathrm{~L}$.

An automatic meteorological station placed 20 meters far from the experimental field continuously monitored air temperature, atmospheric pressure and precipitations (Figure 1). However, during the experiment any precipitation were observed. In the second and the third day after fertilisation, two hours prior to the gas measurements $10 \mathrm{~mm}$ of water were added to each pot for accelerating the beginning of the emissions process.

The observed data were statistically processed using STATISTICA 13.0 (StatSoft, DELL, USA). In order to test the differences of measured (calculated) parameters between the samples Duncan's multiple range tests with the confidence of $\mathrm{P} \leq 0.05$ was performed.

Table 2. Elemental characterisation of tested fertilisers.

\begin{tabular}{lccc} 
& Urea & Digestate & Compost \\
$\mathrm{N}$ content total\% & 46 & 0.319 & 2.27 \\
$\mathrm{~N}-\mathrm{NH}_{4}{ }^{+\%}$ & - & 0.284 & 0.15 \\
\hline $\mathrm{N}-\mathrm{NO}_{3}{ }^{-} \%$ & - & 0.035 & 0.0013 \\
$\mathrm{P}$ content total\% & - & 1.84 & 0.34 \\
\hline $\mathrm{K}$ content total\% & - & 6.94 & 0.97 \\
\hline
\end{tabular}

\section{Results}

\section{Carbon dioxide}

Observed data from 26-measurement days showed that $\mathrm{CO}_{2}$ was the most emitted gas from all fertilisers, although a high variability in the amount of emissions was observed (Table 3 ).

The highest rate of $\mathrm{CO}_{2}$ emissions was produced by digestate. In particular, emissions were more than ten times higher than the other treatments in OM1 (23.24 $\mathrm{Kg} \mathrm{CO}_{2}-\mathrm{C} \mathrm{ha}^{-1}$ day $\left.^{-1}\right)$, and more than three-to-four times than other treatments in OM2 $(26.14 \mathrm{Kg}$ $\mathrm{CO}_{2}-\mathrm{C} \mathrm{ha}{ }^{-1}$ day $\left.^{-1}\right)$. As for digestate, emissions from other fertilisers were positively affected by the increase of OM into the soil. In all treatments, emissions were higher compared to control with the exception of compost in OM1 that produced less $\mathrm{CO}_{2}$ than control. Emissions trend show a specific behavior for each treatments (Figure 2). Urea and compost (and control) emit 16-30 $\mathrm{Kg} \mathrm{CO}_{2}$ $\mathrm{C} / \mathrm{ha}$ /day and, except for urea in OM2, emissions increased until the third-fourth day and then decreased following a similar trend. In OM2, urea produced the highest amount of emissions in the first days and then emissions decrease regularly. Digestate showed the highest daily emission of 327 (OM2) and 259 (OM1) of $\mathrm{Kg} \mathrm{CO}_{2}$ $\mathrm{C} \mathrm{ha}^{-1}$ day $^{-1}$. At the end of the measurement period, $\mathrm{CO}_{2}$ emissions were still observed.
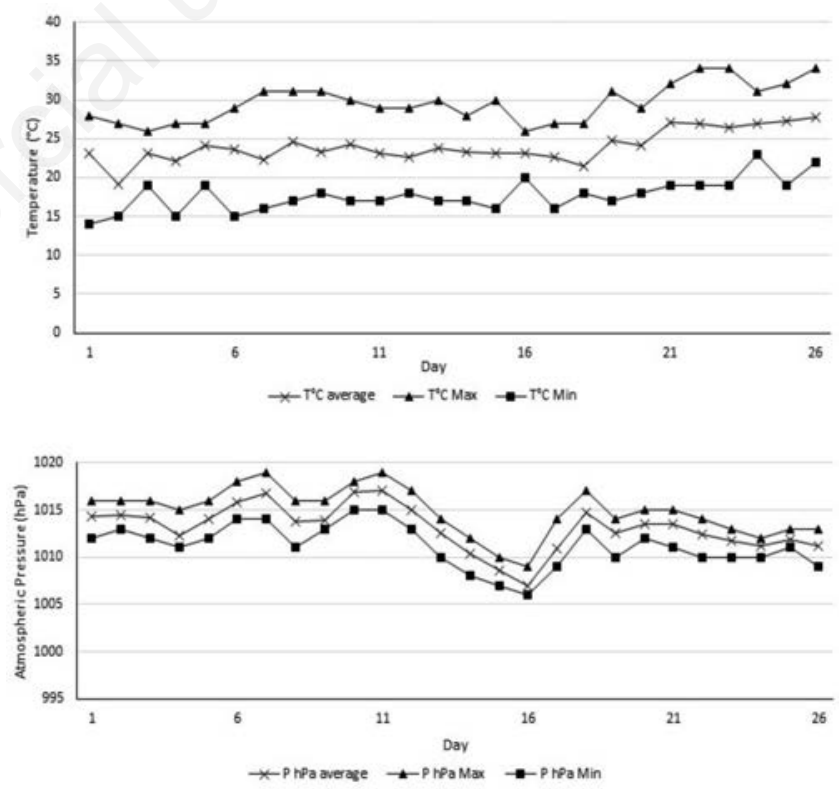

Figure 1. Temperature $\left({ }^{\circ} \mathrm{C}\right)$ and atmospheric pressure trend $(\mathrm{hPa})$.

Table 3. Cumulative emission fluxes on 26-days measuring period for each fertiliser and OM rate.

\begin{tabular}{|c|c|c|c|c|c|c|c|c|}
\hline & \multicolumn{2}{|c|}{$\mathrm{kg} \mathrm{CO}_{2}-\mathrm{Cha}^{-1}$} & \multicolumn{2}{|c|}{$\mathrm{kg} \mathrm{CH}_{4}-\mathrm{Cha}^{-1}$} & \multicolumn{2}{|c|}{$\mathrm{kg} \mathrm{N}_{2} \mathrm{O}-\mathrm{N} \mathrm{ha}^{-1}$} & \multicolumn{2}{|c|}{$\mathrm{kg} \mathrm{NH}_{3}-\mathrm{Nha}^{-1}$} \\
\hline & OM1 & OM2 & OM1 & OM2 & OM1 & 0M2 & OM1 & OM2 \\
\hline No-fertiliser & $38.50^{\mathrm{g}}$ & $129.19^{\mathrm{e}}$ & $8.06^{\mathrm{d}}$ & $8.06^{\mathrm{d}}$ & $0.04^{c}$ & $0.31^{\mathrm{bc}}$ & $0.00^{\mathrm{e}}$ & $0.06^{\mathrm{de}}$ \\
\hline Digestate & $604.12^{\mathrm{b}}$ & $679.75^{\mathrm{a}}$ & $15.07^{a}$ & $12.65^{b}$ & $0.96^{\mathrm{b}}$ & $7.65^{\mathrm{a}}$ & $0.61^{\mathrm{b}}$ & $0.59^{b}$ \\
\hline Urea & $67.04^{\mathrm{f}}$ & $206.67^{\mathrm{c}}$ & $8.95^{\mathrm{d}}$ & $11.17^{\mathrm{bc}}$ & $0.09^{c}$ & $0.29^{b c}$ & $0.09^{\mathrm{de}}$ & $1.15^{\mathrm{a}}$ \\
\hline Compost & $29.22^{\mathrm{h}}$ & $169.35^{\mathrm{d}}$ & $9.62^{\mathrm{cd}}$ & $8.38^{d}$ & $0.03^{c}$ & $0.38^{\mathrm{bc}}$ & $0.26^{\text {cde }}$ & $0.54^{\mathrm{bc}}$ \\
\hline
\end{tabular}

Values marked with the same letter for each gas do not differ significantly according to Duncan's multiple range tests. 


\section{Methane}

In contrast with previous results, digestate and compost produced more $\mathrm{CH}_{4}$ emissions in correspondence of the lower $\mathrm{OM}$ content of soil. If for digestate differences are significant in compost they are negligible (Table 3 ). $\mathrm{CH}_{4}$ emissions from urea were still higher in OM2 than in OM1. For all fertilisers, emissions decreased immediately after spreading; at day 5, an increase in the emissions from urea in OM2 and from digestate, and compost, in OM1 were observed (Figure 3). As for $\mathrm{CO}_{2}$, at the end of measurement period $\mathrm{CH}_{4}$ emissions were still occurring.

\section{Nitrous oxide}

In accordance to $\mathrm{CO}_{2}$ fluxes, $\mathrm{N}_{2} \mathrm{O}$ emissions were positively correlated to OM content of soil. However, significant differences were observed only for digestate that produced roughly seven times more $\mathrm{N}_{2} \mathrm{O}$ in OM2 than in OM1 (Table 3). For all treatments $\mathrm{N}_{2} \mathrm{O}$ was produced a few days after fertilisers spreading in correspondence of irrigation. A peak of emissions in the third day was observed; then emissions decreased regularly until complete depletion in the first week, for urea, and in the second week for digestate and compost (Figure 4).

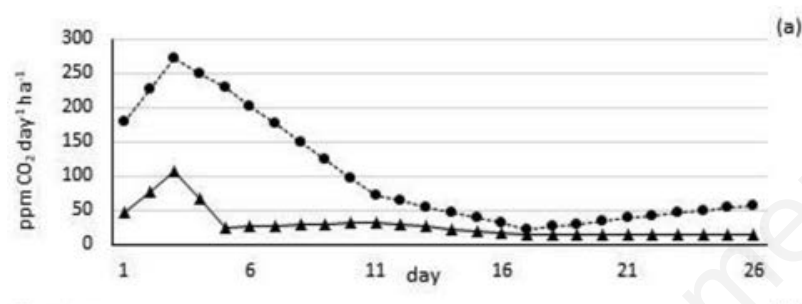

(a)
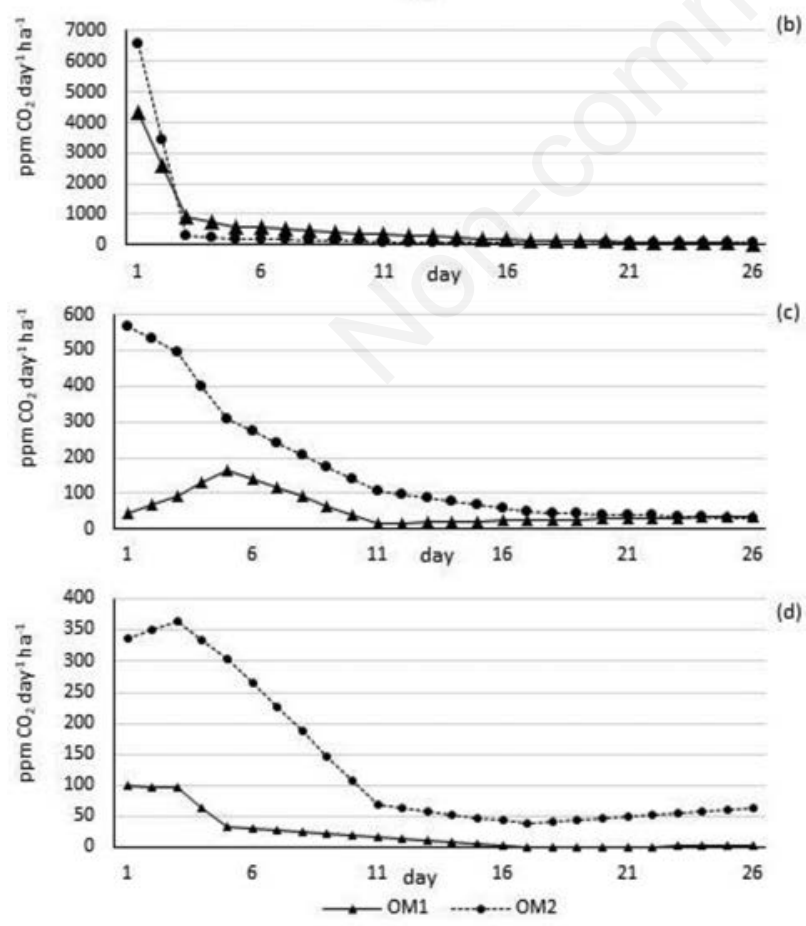

Figure 2. Daily $\mathrm{CO}_{2}$ emission trend (parts per million) on 26-day measuring period for control (A), digestate (B), urea (C) and compost (D) at OM1 ( $\triangle$ ) and OM2 (O).

\section{Ammonia}

Any influence of $\mathrm{OM}$ on $\mathrm{NH}_{3}$ emissions from bare soil was observed (Table 3). All fertilisers produced a similar amount of $\mathrm{NH}_{3}$ emissions. The only exception was represented by urea in $\mathrm{OM} 2$ that showed a higher production of $\mathrm{NH}_{3}$. However, the main part of the emissions were produced by urea in OM2 during the first day after fertilisation. For all fertilisers emissions occurred only during the first week, with complete emission depletion on the fifth day. Urea in OM2 and compost in both OM levels had the highest emission rate on the first day and a regular decrease in the following days. Urea on OM2 and digestate in both OM levels had a peak of emissions on the third day with a consequentially complete depletion on the fifth day, as other treatments (Figure 5).

\section{Discussion}

In this experiment, GHGs and $\mathrm{NH}_{3}$ emissions were measured in absence of crop, so that no $\mathrm{C}$ and $\mathrm{N}$ removal from plant uptake occurred and soil nutrients content was assumed constant during the measurement period. This may have caused higher emission
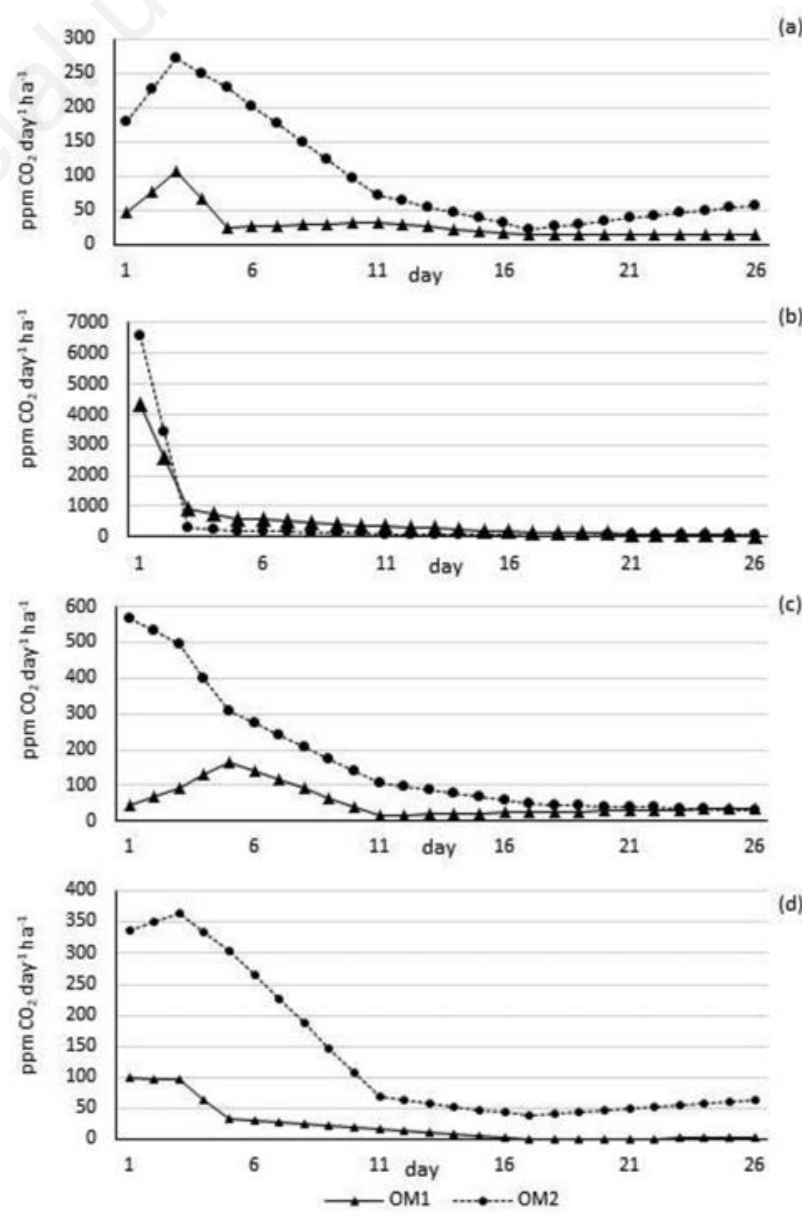

Figure 3. Daily $\mathrm{CH}_{4}$ emission trend (parts per million) on 26-day measuring period for control (A), digestate (B), urea (C) and compost (D) at OM1 (A) and OM2 (O). 
compared to open field conditions. However, especially for compost, fertilisers are often applied several weeks before crop sowing. In this period, between soil fertilisation and the presence of the crop in the field, $\mathrm{C}$ and $\mathrm{N}$ mineralisation and nitrification, with consequent emissions, may occur. In this context, a careful evaluation of most appropriate agronomic strategies to mitigate the risk of emissions is needed. In addition, soil temperature into the plot might be higher than in open field conditions, thus causing higher emissions. Nevertheless, the relative difference among treatments is not affected. Further studies on emission dynamics from open field bare soil are needed for a more in depth understanding of the process.

\section{Carbon dioxide emissions}

$\mathrm{CO}_{2}$ is produced in soil as result of decomposition of organic material by microorganisms and root respiration (Schlesinger and Andrews, 2000). In accordance to that, results show that an enrichment in soil $\mathrm{OM}$ content positively affects $\mathrm{CO}_{2}$ emissions. As affirmed by several authors, $\mathrm{CO}_{2}$ emissions dynamics from agricultural soil are affected by a wide range of factors (Six et al., 1999; La Scala et al., 2000; Paustian et al., 2000). In this respect, OM represents one of the main ones due to its influence on soil res- piration. A higher soil $\mathrm{OM}$ is able to increased soil respiration and consequently $\mathrm{CO}_{2}$ emissions, as observed in the experiment. Digestate produced higher emissions compared to urea. In particular, this is due to digestate composition, rich in water, which allows the infiltration into the soil. An enrichment of water content of soil combined to the mild air temperatures occurred probably encouraged the proliferation of soil microorganisms and consequentially soil respiration. However, as observed by Maucieri et al. (2016), $\mathrm{CO}_{2}$ emissions immediately decreased after fertiliser spreading in both OM levels and differences between OM1 and OM2 were not statistically significant.

Urea produced a higher level of $\mathrm{CO}_{2}$ compared to compost, and the role of $\mathrm{OM}$ was evident. In fact, cumulative $\mathrm{CO}_{2}$ emissions in OM2 were more than 3 times higher than in OM1. This effect was also enhanced by irrigation that ensured hydrolysis of urea with a consequent production of $\mathrm{CO}_{2}$. As observed by Schlesinger and Andrews (2000) $\mathrm{CO}_{2}$ emissions are related to soil respiration following organic residues degradation. In agricultural soils the presence of crops and crop residues continuously provide organic materials for degradation. These observations are in accordance to ours were $\mathrm{CO}_{2}$ emissions were still occurring, in all treatments, at the end of measuring period.
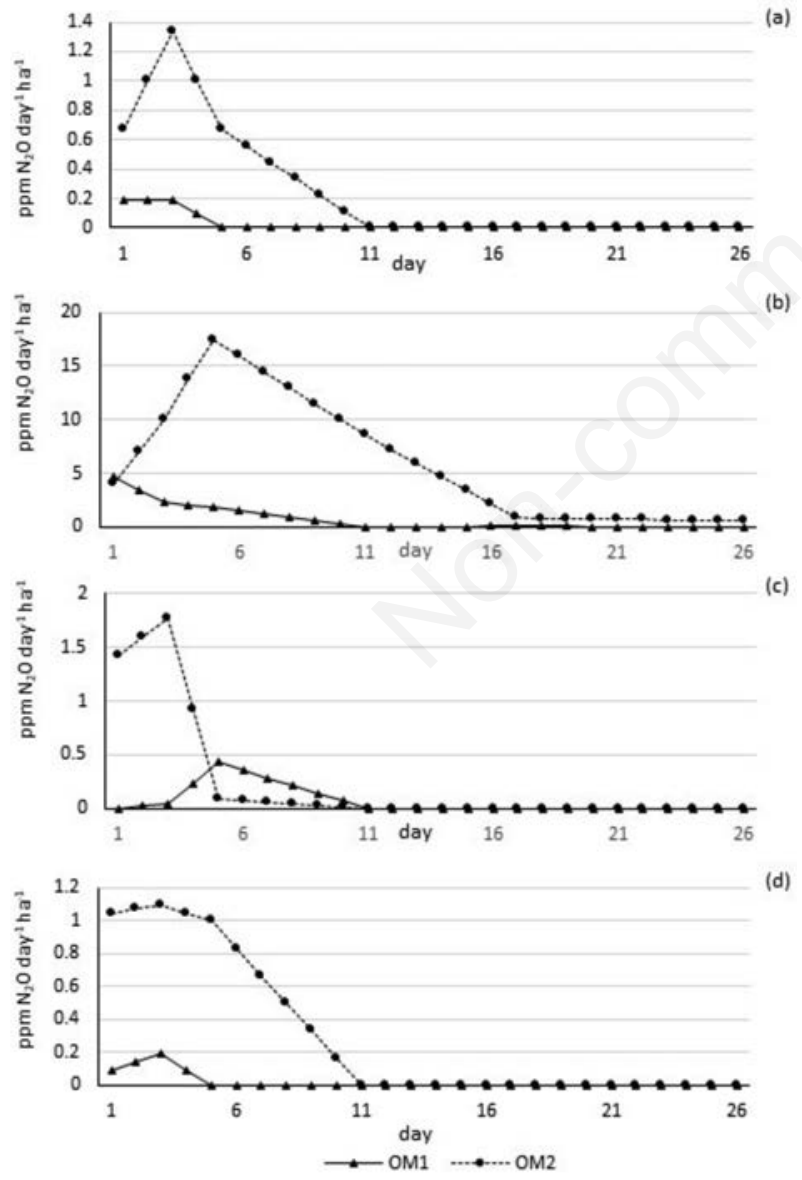

Figure 4. Daily $\mathrm{N}_{2} \mathrm{O}$ emission trend (parts per million) on 26-day measuring period for control (A), digestate (B), urea (C) and compost (D) at OM1 $(\Delta)$ and OM2 $(\mathrm{O})$.

(a)

(b)

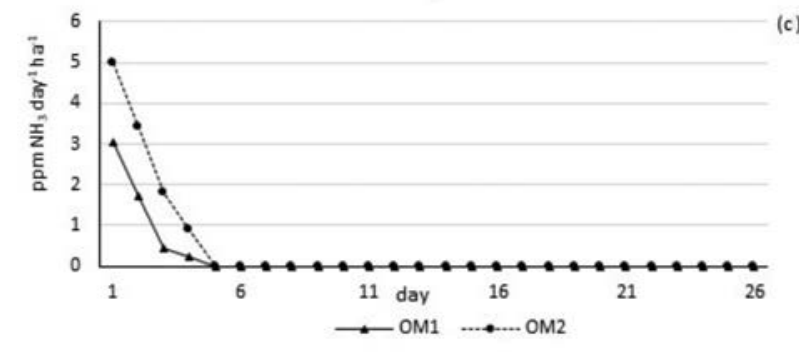

Figure 5. Daily $\mathrm{NH}_{3}$ emission trend (parts per million) on 26-day measuring period for control (A), digestate (B), urea (C) and compost $(\mathrm{D})$ at $\mathrm{OM} 1(\Delta)$ and $\mathrm{OM} 2(\mathrm{O})$. 


\section{Methane emissions}

Results obtained from manures (digestate and compost) showed that $\mathrm{CH}_{4}$ had an opposite trend compared the other gasses monitored. In particular, digestate and compost produced more emissions in OM1 than in OM2. As described by Le Mer and Roger (2001) $\mathrm{CH}_{4}$ emissions from soil are again affected by many factors and a negative correlation between $\mathrm{CH}_{4}$ emissions and $\mathrm{C} / \mathrm{N}$ ratio was reported. An enrichment of available $\mathrm{C}$ stimulates the population soil microorganisms that use a great part of $\mathrm{C}$ for their metabolism with a reduction of available $\mathrm{C}$ for $\mathrm{CH}_{4}$ production (Bernet et al., 2000; Norberg et al., 2016). In this respect, the composition of manure used to obtain the two levels of OM, which represent the $25 \%$ of total organic C, partially explain the behavior of $\mathrm{CH}_{4}$ emissions from organic fertilisers. In addition, the composition of organic fertilisers, rich in total organic C (34.5\% and 25.6\% for digestate and compost, respectively), may have reduced $\mathrm{CH}_{4}$ emissions. Moreover, an addiction of liquid (digestate) and fine milled (compost) fertilisers to the soil may had created compaction and so anaerobic conditions that modified the balance between denitrifying and methanogenic bacteria, in favor of the first ones (Saggar et al., 2004; Bunemann et al., 2006). In the case of urea, that does not contain organic $\mathrm{C}$, the positive correlation between $\mathrm{OM}$ level and $\mathrm{CH}_{4}$ emissions was confirmed.

\section{Nitrous oxide emissions}

Results obtained demonstrated that $\mathrm{N}_{2} \mathrm{O}$ emissions are positively affected by the OM content of soil. For all tested fertilisers $\mathrm{N}_{2} \mathrm{O}$ emissions in OM2 were higher than in OM1. In particular, digestate produced the highest emissions and this was due to its high water content and irrigation that determines anaerobic conditions with consequent higher $\mathrm{N}_{2} \mathrm{O}$ losses compared to the other fertilisers (Wulf et al., 2002). Moreover, the higher amount of organic $\mathrm{C}$ available into the soil in OM2 probably encouraged denitrification activity and $\mathrm{N}$ degradation (Velthof et al., 2003). The high rate of readily available $\mathrm{N}$ compounds of digestate and the mild temperature occurred during the experiment (average of $28.4^{\circ}$ ) enhanced $\mathrm{N}$ losses in the first two weeks after fertilisation. On the other hand, compost emitted a $\mathrm{N}_{2} \mathrm{O}$ rate comparable with the control, probably due to its low water content and its stable chemical composition. This result, in fact, is in accordance with the findings of Dalal et al. (2010), confirming that the application of compost can be considered an efficient strategy to reduce $\mathrm{N}_{2} \mathrm{O}$ emissions. Moreover, differences on emissions between the two fertilisers are in accordance to Aguilera et al. (2013) that found more $\mathrm{N}_{2} \mathrm{O}$ emissions from liquid than solid organic fertilisers. Finally, concerning urea, its low water content reduces the risk of anaerobic conditions at soil level and the consequent $\mathrm{N}_{2} \mathrm{O}$ emissions that are comparable with those of compost. Further, during hydrolysis the majority of $\mathrm{N}$ contained in urea is transformed into $\mathrm{NH}_{3}$ with a reduction of $\mathrm{N}$ available for denitrification.

\section{Ammonia emissions}

$\mathrm{NH}_{3}$ emissions were nearly five times higher in OM2 than OM1 treated with urea. Again, this confirms that higher organic $\mathrm{C}$ content into the soil modifies the $\mathrm{C} / \mathrm{N}$ ratio and encourages bacteria activity with greater degradation of $\mathrm{N}$ and $\mathrm{NH}_{3}$ losses. Moreover, as observed by Rochette et al. (2013), the increase of soil $\mathrm{pH}$ caused by urea hydrolysis encouraged $\mathrm{NH}_{3}$ volatilisation losses. Further, $\mathrm{NH}_{3}$ emissions were also favored by irrigation. On the other hand, contribution of manure, used for soil OM enrichment to $\mathrm{NH}_{3}$ emissions, can be consider negligible due to its neutral (7) $\mathrm{pH}$.
Digestate and compost are an exception: digestate showed the highest rate of $\mathrm{NH}_{3}$ emissions of them. However, no differences between emissions in the two OM levels were observed. As on digestate, also on compost no significant differences were observed between the OM levels. This suggests that OM content of soil does not affect $\mathrm{NH}_{3}$ volatilisation dynamics. Moreover, the neutral $\mathrm{pH}$ of digestate (7.7) and compost (6.8) had reduced $\mathrm{NH}_{3}$ volatilisation losses compared to urea.

\section{Conclusions}

This experiment was performed to evaluate the effect of soil organic matter on GHGs emissions that occur from soil after fertilisation with different fertilisers. A wide range of factors affects emission dynamics into the soil, however, organic matter is one of them and plays a key role, generally enhancing the levels of GHGs emissions. In addition, fertiliser spreading emphasises emissions dynamics from soil. In this regard, compost represents an alternative to mineral fertilisers for GHGs and $\mathrm{NH}_{3}$ mitigation. In particular, compared to urea, reduced $\mathrm{CH}_{4}$ and $\mathrm{N}_{2} \mathrm{O}$, and comparable $\mathrm{CO}_{2}$ and $\mathrm{NH}_{3}$ make compost an interesting strategy for sustainable fertilisation management.

However, further investigations in open field are needed to exclude the influence of pot. Likewise, $\mathrm{CH}_{4}$ emission dynamics from digestate and compost require additional studies that consider soil microorganisms population.

\section{References}

Aguilera E, Lassaletta L, Sanz-Cobena A, Garnier J, Vallejo A, 2013. The potential of organic fertilizers and water management to reduce $\mathrm{N}_{2} \mathrm{O}$ emissions in Mediterranean climate cropping systems. A review. Agr. Ecosyst. Environ. 164:32-52.

Alburquerque JA, de la Fuente C, Campoy M, Carrasco L, Nájera I, Baixauli C, Caravaca F, Roldán A, Cegarra J, Bernal M P, 2012. Agricultural use of digestate for hoeticultural crop production and improvement of soil properties. Eur. J. Agron. 43:119-28.

Alluvione F, Bertora C, Zavattaro L, Grignani C, 2010. Nitrous Oxide and Carbon Dioxide emissions following green manure and compost fertilization in corn. Soil Sci. Soc. Am. J. 74:38495.

Bernet N, Delgenes N, Akunna JC, Delgenes JP, Moletta R, 2000. Combined anaerobic - aerobic SBR for the treatment of piggery wastewater. Water Res. 34:611-9.

Bouwman L, Stehfest E, van Kessel C, 2010. Nitrous oxide emissions from the nitrogen cycle in arable agriculture: estimation and mitigation. In: Smith K (ed.) Nitrous oxide and climate change. Earthscan Ltd., London, UK, pp 85-106.

Bunemann EK, Schwenke GD, Van Zwieten L, 2006. Impact of agricultural inputs on soil organisms - a review. Aust. J. Soil Res. 44:379-406.

Hayakawa A, Akiyama H, Sudo S, Yagi K, 2009. $\mathrm{N}_{2} \mathrm{O}$ and NO emissions from an Andisol field as influenced by pelleted poultry manure. Soil Biol. Biochem. 41:521-9.

Huang Y, Zou J, Zheng X, Wang Y, Xu X, 2004. Nitrous oxide emissions as influenced by amendment of plant residues with different C:N ratios. Soil Biol. Biochem. 36:973-81.

Le Mer J, Roger P, 2001. Production, oxidation, emission and con- 
sumption of methane by soils: a review. Eur. J. Soil Biol. 37:25-50.

La Scala N, Marques J Jr, Pereira GT, Corá JE, 2000. Carbon dioxide emission related to chemical properties of a tropical bare soil. Soil Biol. Biochem. 32:1469-73.

Lopez-Fernandez S, Diez JA, Hernaiz P, Arce A, Garcia-Torres L, Vallejo A, 2007. Effects of fertilizer type and the presence or absence of plants on nitrous oxide emissions from irrigated soils. Nutr. Cycl. Agroecosys. 78:279-89.

Mamo M, Rosen CJ, Halbach TR, 1999. Nitrogen availability and leaching from soil amended with municipal solid waste compost. J. Environ. Qual. 28:1074-82.

Maucieri C, Barbera A C, Borin M, 2016. Effect of injection depth of digestate liquid fraction on soil carbon dioxide emission and maize biomass production. Ital. J. Agron. 11:6-11.

Miller FP, Wali MK, 1995. Soils, land use and sustainable agriculture: a review. Canadian J. Soil Sci. 75:413-22.

Minoli S, Acutis M, Carozzi M, 2015. $\mathrm{NH}_{3}$ emissions from land application of manures and $\mathrm{N}$-fertilizers: a review of the Italian literature. Ital. J. Agrometeorol. 3:5-24.

Norberg L, Berglund O, Berglund K, 2016. Nitrous oxide and methane fluxes during the growing season from cultivated peat soils, peaty marl and gyttja clay under different cropping systems. Acta Agr. Scand. B-S P. 66:602-12.

Oertel C, Matschullat J, Zurba K, Zimmermann F, Erasmi S, 2016. Greenhouse gas emissions from soils - A review. Chem. ErdeGeochem. 76:327-52.

Palm CA, Giller KE, Mafongoya PL, Swift MJ, 2001. Management of organic matter in the tropics: translation theory into practice. Nutr. Cycl. Agroecosys. 61:63-75.

Parkin TB, Venterea RT, 2010. USDA-ARS GRACEnet Project Protocols, Chapter 3. Chamber-Based Trace Gas Flux Measurements. (Replace original version of April 2003).

Paustian K, Six J, Elliott ET, Hunt HW, 2000. Management options for reducing $\mathrm{CO}_{2}$ emissions froma gricultural soils. Biogeochemistry 48:147-63.

Pezzolla D, Bol R, Gigliotti G, Sawamoto T, Lopez AL, Cardenas L, Chadwick D, 2012. Greenhouse gas (GHG) emissions from soils amended with digestate derived from anaerobic treatment of food waste. Rapid Commun. Mass Sp. 26:2422-30.

Rochette P, Angers DA, Chantigny MH, Gasser MO, MacDonald
JD, Pelster DE, Bertrand N, 2013. $\mathrm{NH}_{3}$ volatilization, soil $\mathrm{NH}_{4}{ }^{+}$concentration and soil $\mathrm{pH}$ following subsurface banding of urea at increasing rates. Can. J. Soil Sci. 93:261-8.

Rowell DM, Prescott CE, Preston CM, 2001. Decomposition and nitrogen mineralization from biosolids and other organic materials: relationship with initial chemistry. J. Environ. Qual. 30:1401-10.

Saggar NS, Bolan R, Bhandral CB, Hedley JL, 2004. A review of emissions of methane, ammonia, and nitrous oxide from animal excreta deposition and farm effluent application in grazed pastures. New Zeal. J. Agr. Res. 47:513-44.

Schlesinger WH, Andrews JA, 2000. Soil respiration and the global carbon cycle. Biogeochemistry 48:7-20.

Six J, Elliott E T, Paustian K, 1999. Aggregate and soil organic matter dynamics under conventional and no-tillage systems. Soil Sci. Soc. Am. J. 63:1350-8.

Stehfest E, Bouwman L, 2006. $\mathrm{N}_{2} \mathrm{O}$ and NO emission from agricultural fields and soils under natural vegetation: summarizing available measurement data and modeling of global annual emissions. Nutr. Cycl. Agroecosys. 74:207-28.

Vallejo A, Skiba UM, Garcia-Torres L, Arce A, Lopez-Fernandez S, Sanchez-Martin L, 2006. Nitrogen oxides emission from soils bearing a potato crop as influenced by fertilization with treated pig slurries and composts. Soil Biol. Biochem. 38:2782-93.

van Groenigen JW, Kasper GJ, Velthof GL, van den Pol-van Dasselaar A, 2004. Nitrous oxide emissions from silage maize fields under different mineral nitrogen fertilizer and slurry applications. Plant Soil 263:101-11.

Velthof GL, Kuikman P, Oenema O, 2003. Nitrous oxide emission from animal manures applied to soil under controlled conditions. Biol. Fert. Soils 37:221-30.

Walsh JJ, Jones DL, Edward-Jones G, Williams AP, 2012. Replacing inorganic fertilizer with anaerobic digestate may maintain agricultural productivity at less environmental cost. J. Plant Nutr. Soil Sci. 175:840-5.

Wulf S, Maeting M, Clemens J, 2002. Application technique and slurry co-fermentation effects on ammonia, nitrous oxide, and methane emissions after spreading II. Greenhouse gas emissions. J. Environ. Qual. 31:1795-801. 